\title{
An Evaluation of Retail Banking Products' Performance: A Study on Selected Bankers
}

\author{
Md. Siraz Meah ${ }^{1} \&$ Md. Sarwar Uddin ${ }^{1}$ \\ ${ }^{1}$ Assistant Professor, Faculty of Business Administration, BGC Trust University Bangladesh, Bangladesh \\ Correspondence: Md. Sarwar Uddin, Associate Professor, Faculty of Business Administration, BGC Trust \\ University Bangladesh, Bangladesh. E-mail: sarwaredu@gmail.com
}

Received: January 28, 2021

Accepted: February 16, 2021

Online Published: April 11, 2021

doi:10.5539/ijbm.v16n5p115

URL: https://doi.org/10.5539/ijbm.v16n5p115

\begin{abstract}
The study has examined to categorize the retail banking products according to their important performance on scheduled commercial banks operating in Chittagong, Bangladesh. To do this, the authors have collected data from 118 bankers who are working at different level in different banks. Data have been analyzed with the help of SPSS IBM (Statistical Package for Social Science) 21.0 version. Factor analysis as well as multiple regression analysis has been conducted to get the result. Bartlett's Test of Sphericity along with Kaiser-Meyer-Olkin (KMO) statistics has been used to highlight three (03) categories retail products responsible for retail banking products' performance of scheduled commercial banks. The study has found that these three (03) categories could explain $59.169 \%$ of total variability of retail banking products' performance. Finally, multiple regression analysis has suggested that these three (03) categories of retail products influenced retail banking products' performance most significantly. Limitations and further research directions are also discussed.
\end{abstract}

Keyword: scheduled commercial banks, retail banking products' performance, categories of retail banking products

\section{Introduction}

There was "World Retail Banking Report", which was published in Holland, $28^{\text {th }}$ march, 2007. According to this report, active users or customers of retail banking products globally paid at $€ 77$ (average price) which was decreasing price at $0.3 \%$ than last year. However, this change had some variations such as $1.8 \%$ reduced in the Euro zone and 2.9\% improved in Asia pacific (Yesmin \& Nasrin, 2010). In these circumstances, retail banking was inaugurated in 1960's. In Bangladesh, nationalized bank (Sonali Bank) has started it through BIKALPA in early 1990's. However, the "new retail" model was emerging in the mid 1990's as alternative retail channels such as Automated Teller Machine (ATM), call centre, internet etc. (Business week, 1994).

In Bangladesh, Banking industry is matured largely than before. It has developed superb image in their various activities including retail banking. As ever-growing middles class population and rising income levels have combined with demographic change of smaller business household sizes has boosted demand for retail banking products. However, increasing population, increasing in the number of households, per capital income, number of employed people and per capital household income etc. provide the need for fulfilling the gap between the existing level of debt and income.

As technologies are changing rapidly and transactions are operational, there is opportunity for bank to develop more retail banking products. Later on various types of retail banking products were offered by commercial banks. These available retail-banking products are checking and savings a/c, consumer credit, personal loan, and so forth. Consumer credit schemes include credit cards mortgages, home equity lending auto loans, education loans, and other personal loans. Although loans and deposits are the basic products, retail-banking units provide a range of other financial services to customers and small businesses. For this reason retail banking system is new avenue for research and development in the banking sector. Therefore, in a retail-banking context, a bank client has perceived level of product quality which is more likely to determine whether or not he/she would be motivated to get involved in any types of interaction with the bank's employee, eventually enhancing his /her satisfaction with the bank.

At present, each and every bank has been providing more services to the customers. Therefore, there is a 
competition among banks to provide more services to the customers. In this competition, the bank which will go ahead will be more benefited than others. There are 86 different scheduled commercial banks working together in Bangladesh. The competition is giving up day after day by giving better services and they are trying to develop their own services every now and then. Recently retail banking has tremendous importance in banking sector and bankers' customer as well. This is why; researchers find some interest to explore something regarding retail banking in some extent.

\section{Literature Review}

There are different concepts of retail banking product quality. According to Wang et al. (2003) have opinioned and viewed the quality as product attribute in the marketing and economics context. Product quality is measured as an overall assessment and multiple dimensions according to the service point of view (Parasuaraman et al., 1988). Quality has been viewed in terms of products attribute. In contrasts, in the field of operation management, Garvin (1988) has showed that product quality comprises eight (8) attributes: performance, characteristics, conformance, reliability, permanence, serviceability, aesthetics, and customer perceived quality.

Roy and Khan (2013) studied on private commercial banks in Bangladesh. They analyzed 08 retail banking products' quality, which are not highly significant for bank reputation, 08-retail banking service quality, which was highly significant for bank reputation and 05 factors of social responsibility was also highly significant for bank reputation.

Yesmin and Nusrin (2010) worked on improvement of retail banking products in Bangladesh. In this study, the authors took 28 listed banks as a sample. The study has found that sample banks have offered different types of retail products (deposit increases by $88.18 \%$ ), loan product increased by $48.50 \%$ and card services by $21.15 \%$ by increasing the number of branches by $19.28 \%$. The authors have tried to analyze the average value of the overall performance of retail products. By using average value, they found that loan products were the highest position among the retail products offered to the people by bank.

De Young and Rice (2004) showed two (2) types of banks such as "traditional banks" and "non-traditional" banks. Between them, traditional banks have offered relatively large core deposit ratios and low volatility of income. On the other hand, non-traditional bank provides a wide range of services. There is a need for constant innovation in retail banking. Bank now needs to use growth trigger for retail banking services. To do it, retail banks need product segmentation, product customization, product development, product analysis, product engineering, micro planning, product pricing, customization, technological adaption, online banking, cost minimization and cross-servicing.

Biswas and Yesmin (2010) researched with taking banking and non-banking financial institutions in Bangladesh. They investigated the performance of 10 retail products from the employees' viewpoint. The 10 retail products are -retail savings product and services, retail consumer credit, SME products, evening banking/ services, electronic banking/ services, online banking/ services, research and development, IT development, agriculture etc. They indicated three categories of those products for analyzing purposes. In the analysis, the first and second categories are highly significant for retail products' performance of the listed sample banks.

Rahman et al., (2017) have observed that the customers of Dutch Bangla Bank Limited (DBBL) are not enough knowledge regarding retail banking products especially electronic banking not only Chittagong but also over the country. The following key points are: effective use of corporate governance, keeping accountability and transparency in all respects, lessening political interference, bankers' efficiency, and efficient handling risk management may remove the overall retail banking problem in Bangladesh (Chowdhury \& Dhar, 2012).

The review of literatures suggest that many studies have been conducted on retail banking products operation, retail banking products evaluation, retail banking and customer satisfaction, growth of retail banking products etc. in a variety of undertaken over the world. However, Bankers' perspective on retail banking products performance of listed commercial banks in Bangladesh has not yet been recognized. Therefore, the study is designed to emphasize on the performance of retail banking product in the viewpoint of bankers, which will be most significant to contribute the total performance of retail banking products in the scheduled commercial banks operating in Chittagong, Bangladesh.

\section{Aims of the Study}

The prime aim of the study is to evaluate the retail banking products performance of scheduled commercial banks operating in Chittagong. To accomplish the main objective, the following specific objectives have been covered:

i) To classify the retail banking products according to their performance. 
ii) To know the individual influences of retail banking products performance.

iii) To find out the limitation and provide suggestions to the bank authority.

\section{Research Methodology}

The methodology includes questionnaire design, sample design, data processing techniques and reliability of data. This research is based on the primary data, which is analysis to assess the performance of retail banking products on the bankers' perspective.

\subsection{Questionnaire Design}

According to the above literature review, a structural questionnaire was developed adopting ten (10) questions regarding retail banking product factors. At the end of question, the last and final question "Perception of corporate retail products' performance of your institution" was included. The questionnaire was prepared following the Likert's five-point scale which is developed by Likert (1967), recording ' 4 ' and ' 5 ' represent good performance of retail products, the more the score, the more the level of product performance. Similarly, recording ' 1 ' and ' 2 ' represent the poor performance of retail products, the less the score, and the less level of product performance. Remaining ' 3 ' represents neither good nor poor with the items.

\subsection{Sample Design}

For conducting the study, the total numbers of 07 scheduled commercial banks in Chittagong were selected randomly. The authors prepared 180 structured questionnaires were sent to the respondents for collecting data. Among the questionnaires, 118 respondents gave their feedback. They filled up all the questions without missing any figure. Thus, all the 118 questionnaires were finally selected for analysis. The scheduled commercial banks taken for the study are First Security Islami Bank Limited (FSIBL), National Bank limited (NBL), Dutch Bangla Bank limited (DBBL), Janata Bank limited (JBL), Rupali Bank limited (RBL), Uttara Bank limited (UBL), NRB Global Bank (NRBGB).

\subsection{Data Processing Techniques}

The authors used 21.0 versions of SPSS and excel (2007) to process the data. The variables are inter correlated and thus factor analysis has been used to reduce the number variable into significant factors indicating the performance of retail banking products of scheduled commercial banks operating in Chittagong, Bangladesh. Lastly, they were also used to determine the influence of independent variables (retail banking products) on the dependent variable (perception of overall retail products' performance) with the help of multiple regression analysis. As statistical tools, ANOVA and T-test has been used. ANOVA was used for creating the relationship between the performance of individual retail product factors and perception of overall retail products performance. On the other hand, T-test has been used for interpreting the result at $1 \% \& 5 \%$ level of significance.

\subsection{Reliability of Data}

To measure the variables of the study, reliability is the best way to reflect consistency among the items. The differences among individuals regarding the extent to their agreement and disagreement of the studying variables are illustrated in reliability. The alpha of Cronbach is extensively applied for measuring the scale's reliability (Hair, Anderson, Tatham, \& Black, 2003; Malhotra, 2002; Cooper \& Schindler, 2006). It is necessary to mention that the alpha value of Cronbach is ranged from 00 to 01 , but to make the scale reliable the agreeable level must be more than 0.60 (Malhotra, 2002; Cronbach, 1951). In the present study, the Cronbach's alpha value for the retail banking products is 0.69 .

\section{Data Analysis and Findings}

In this study, 10 variables have been taken into consideration. As the variables are interrelated, factor analysis is essential, that is shown in the following table 1 .

Table 1. Kmo and Bartlett's test

\begin{tabular}{lll}
\hline Kaiser-Meyer-Olkin Statistics. & & 0.667 \\
\hline & Approx. Chi-Square & 257.014 \\
Bartlett's Test of Sphericity & Df & 45.00 \\
& Sig. & 0.000 \\
\hline
\end{tabular}

Source: Author's own calculation. 
Here, The KMO value is 0.667 , which is between 0.5 and 1.0 and so factor analysis is appropriate (Hadi \& Islam, 2015). On the other hand, Chi square test is 257.014 with 45 degrees of freedom, which is significant at the 0.05 level. Thus, factor analysis divulges the most significant factors that contribute to measure the performance of retail banking products of commercial banks operating in Chittagong, Bangladesh.

Table 2. Total Variance Explained

\begin{tabular}{lllllll}
\hline \multirow{2}{*}{ Component } & \multicolumn{2}{c}{ Initial Eigen values } & \multicolumn{3}{c}{ Extraction Sums of Squared Loadings } \\
& Total & \% of Variance & Cumulative \% & Total & \% of Variance & Cumulative \% \\
\hline 1 & 2.781 & 27.814 & 27.814 & 2.781 & 27.814 & 27.814 \\
2 & 1.799 & 17.986 & 45.800 & 1.799 & 17.986 & 45.800 \\
3 & 1.337 & 13.369 & 59.169 & 1.337 & 13.369 & 59.169 \\
4 & 0.843 & 8.427 & 67.596 & & \\
5 & 0.798 & 7.980 & 75.576 & & \\
6 & 0.694 & 6.938 & 82.513 & & \\
7 & 0.572 & 5.721 & 88.234 & & \\
8 & 0.489 & 4.890 & 93.124 & & & \\
9 & 0.371 & 3.713 & 96.837 & & & \\
10 & 0.316 & 3.163 & 100.000 & & & \\
Extraction Method: Principal Component Analysis & & & & \\
\hline \multicolumn{7}{l}{}
\end{tabular}

In the above table2, only three (03) factors have been extracted, as cumulative percentage is less than $60 \%$, at this point and Eigen values is greater than 1.0 (it is recommend that factor with Eigen values greater than 1.0 should be retained) that indicates the adequacy of this factor analysis with help of deriving factors. These three (3) factors have explained $27.814 \%, 17.986 \%$, and $13.369 \%$ of variability respectively. Therefore, it can be said that total retail banking product performance could explain all together $59.169 \%$ variability of these three categories' retail products of scheduled commercial banks operating in Chittagong, Bangladesh.

Table 3. Rotated component matrix

\begin{tabular}{llll}
\hline & $\begin{array}{l}\text { Component } \\
\text { category } 1\end{array}$ & category & 2 \\
\hline Retail Savings Products & 0.171 & 0.642 & category 3 \\
Retail Consumer Credit Schemes & 0.144 & -0.156 & 0.322 \\
SME financing & -0.108 & 0.539 & 0.849 \\
Evening Banking & 0.537 & 0.529 & 0.301 \\
Electronic Banking & 0.656 & -0.190 & -0.278 \\
Online Banking & 0.611 & -0.259 & -0.339 \\
Research and Development & 0.785 & 0.051 & -0.165 \\
IT development & 0.757 & -0.074 & 0.346 \\
Agriculture and rural credit & 0.333 & 0.702 & -0.028 \\
Credit Card & 0.572 & -0.433 & -0.166 \\
\hline
\end{tabular}

Source: Author's own calculation.

In the above table3, Retail banking products' categories:

Category-1: Most important performing application.

Category-2: important performing application.

Category-3: Less important performing application. 
In the factor analysis, the extracted three (03) categories such as category-1, category-2, category-3, can be interpreted in these variables that load high coefficients. From the rotated component matrix table, category-1 has high coefficients for Evening Banking (0.537), Electronic Banking (0.656), Online Banking (0.611) Research and Development (0.785), IT development (0.757), and Credit Card (0.572). The total variability of this application is explained $27.814 \%$ which is the highest rather than others. Thus, category- 1 can be entitled as "most important performing retail banking products". Category 2 has high coefficients for Retail Savings Products (0.645), SME financing (0.539), and Agriculture \& rural credit (0.702). The total variability of this application is explained $17.986 \%$, which is more than third category. Thus, category-2 can be entitled as "important performing retail banking products". Finally, category 3 has high coefficients for Retail Consumer Credit Schemes (0.849). The total variability of this application is explained $13.369 \%$, which is less than other two categories. Thus, category-3 can be entitled as "less important performing retail banking products". Therefore, it can be said that the variability of the total retail banking product performance of scheduled commercial banks explained as $59.169 \%$.

In order to account for the importance of the independent variables (retail banking products) on the dependent variable (perception of overall retail products performance), and to find out individual contribution of three $(03)$ categories' retail banking products, the authors have extended the analysis which is called multivariate analysis (Multiple regressions). The summary of regression is shown the following table 04:

Table 4. Summary of regression between independent variables and dependent variable

\begin{tabular}{llllllll}
\hline \multirow{2}{*}{$\begin{array}{l}\text { Predictors/Categories } \\
\text { of retail banking products }\end{array}$} & \multicolumn{2}{l}{$\begin{array}{l}\text { Unstandardized } \\
\text { Coefficients }\end{array}$} & $\begin{array}{l}\text { Value } \\
\text { t-statistics }\end{array}$ & & Sig & $\begin{array}{l}\text { Value } \\
\text { of }\end{array} \quad \begin{array}{c}\text { Value } \\
\text { square }\end{array}$ & F-statistics \\
\cline { 2 - 6 } Category-1 & Beta & S.E & & & & \\
Category-2 & 0.463 & 0.106 & 4.374 & 0.000 & & \\
Category-3 & 0.266 & 0.123 & 2.157 & 0.033 & 0.202 & 9.637 \\
\hline
\end{tabular}

Correlation is significant at the level of $1 \%, \& 5 \%, \mathrm{~N}=118$.

The table 4 provides useful information about regression analysis. In the column two (2), "Unstandardized Coefficients" indicates the un-standardized regression coefficients. In the column three (3) and column four (4), the regression coefficient of t-test is different enough from zero to be statistically significant at the level 0.000 , 0.033 , and 0.299 respectively. ' $R$ ' square states the proportion (percentage) of the (sample) variables in the dependent variable and it can also be attributed to the independent variables in column six (6). In the study, the value of R-square is 0.202 . It means that the independent variables explained $20.2 \%$ of the dependent variable. In general, $\mathrm{R}$ square always increases as independent variables are added to a multiple regression model. On the other hand, the larger portions $(79.80 \%)$ of variance in the three $(03)$ categories (category 1 , category 2 , and category 3) of retail banking products were unexplained by independent variables. The reason for unexplained variance suggests that there were other implied variables that account for variance in retail banking products performance. Among three (03) categories, only category 1 was significant at the level of $1 \%$, categories 2 were significant at the level of 5\% statistically and a category 3 was not significant.

In fine, retail banking products such as category 1 , category 2 , are influential and are significant statistically but and category 3 are not significant. Therefore, category 1 and category 2 of retail banking products of scheduled commercial banks are giving significant importance on the perception of overall retail products' performance.

\section{Conclusion}

At present, as financial institutions, commercial banks are extending their corporate exposures through retail banking products' performance as a new dimension. For this reason, the authors found that these retail products in commercial banks are retail savings product and services (deposit scheme such as Deposit Pension Scheme, Fixed Deposit Receipt, monthly benefit scheme, education savings scheme, deposit double scheme, deposit triple scheme etc.), Retail consumer credit scheme (such as home loan, personal loan, car loan, marriage loan, loan against salary etc.), SME products, evening banking/services, electronic banking/services, online banking/services, research and development, IT development, agriculture and rural credit policy and different card services (debit card, credit card, ATM card, visa card, B-kash, Q-cash, M-cash, Rocket etc.). As measurement criteria for these retail products' performances, the authors have surveyed 118 bankers in 07 scheduled commercial banks operating in Chittagong, Bangladesh. From this survey, the author has identified 
three (03) categories such as category-1: most important performing retail products, category-2: important performing retail products, category-3: less important performing retail products. Most important performing retail products are Evening Banking (0.537), Electronic Banking (0.656), Online Banking (0.611) Research and Development (0.785), IT development (0.757), and Credit Card (0.572). Important performing retail products are Retail Savings Products (0.645), SME financing (0.539), and Agriculture \& rural credit (0.702). On the other hand, less important performing retail products are Retail Consumer Credit Schemes $(0.849)$ because most of the respondents were taken from recently scheduled commercial banks. Therefore, these banks should be given more emphasis on Retail Consumer Credit Schemes. Finally through regression analysis, the author has proved that these three (03) category of retail banking products such as category-1 (most important performing product, at the $1 \%$ level of significant), category-2 (important performing product, at the $5 \%$ level of significant), and category-3 (less important performing product, statistically no significant) have highly significant effect on overall retail banking products performance in scheduled commercial banks operating in Chittagong, Bangladesh.

\section{Limitations and Future Research}

The most significant limitation is small sample size (118). The research would have been more reliable if a greater size of the sample had been used. The respondents were selected from 07 branches of 07 scheduled commercial banks located in Chittagong city. This study focused on the perception of bankers regarding retail banking products performance of scheduled commercial banks. However, the perception of other stakeholders is not considered. It is recommended that future research may be conducted to study the perception of depositors, customers and other stakeholders regarding retail banking products performance of scheduled commercial banks in Bangladesh.

\section{References}

Biswas, S., \& Yesmin, F. (2010). Evaluation of retail product performance of listed commercial banking and financial companies of Bangladesh. ASA University Review, 4(2), 181-193.

Business, W. (1994). Another year in "Bank Heaven?” Dhaka, Bangladesh

Chowdhury, R., \&Dhar, B. K. (2012). The Perspective of Loan Default Problems of the commercial Banking Sector of Bangladesh: A Closer Look into the Key Contributory Factors. University of Science and Technology Annual (USTA), 18(1), 71-87.

Cooper, D. R., \& Schindler, P. S. (2006). Business research methods with CD. (9th edition). McGraw-Hill.

Cronbach, L. J. (1951). Coefficient alpha and the internal structure of tests. Psychometrika, 16, 297-334.

DeYoung, R., \& Rice, T. (2004). 'How Do Banks Make Money? The fallacies of fee income'. Economic Perspectives, Federal Reserve Bank of Chicago, 34-51.

Garvin, D.A. (1988). Managing Quality: The Strategic and Competitive Edge. New York: The Free Press.

Hadi, R. S., \& Islam, M. M. (2015). Exploring Entrepreneurial Potentials: The Performance of EMK Center. BGC Trust University Journal, 2, 155-163.

Hair, J., Anderson, R., Tatham, R., \& Black, W. (2003). Multivariate DataAnalysis with Readings. New Jersey: Prentice Hall.

Likert, R. (1967). The method for constructing an attitude scale. In M. Fishbein (Ed.), Readings in attitude theory and measurement (pp. 90-95).New York: Wiley

Malhotra, N. K. (2002). Marketing Research: an applied orientation (3rd ed.), prentice hall international, Inc. Upper Saddle River, New Jersey.

Parasuraman, A., Zeithaml, V. A., \& Berry, L. L. (1988). SERVQUAL: a multiple-item scale for measuring consumer perceptions of service quality. Journal of Retailing, 64(1), 12-40.

Rahman, M., Saha, N. K., Sarker, M. N. I., Sultana, A., \& Prodhan, S. A. Z. M. (2017). Problems and Prospects of Electronic Banking in Bangladesh: A Case Study on Dutch-Bangla Bank Limited, American Journal of Operations Management and Information Systems; 2(1), 42-53. https://doi.org/10.11648/j.ajomis.20170201.17

Roy, M.K., \& Khan, S.H. (2013). Study on Private Commercial Banks in Bangladesh.ASA University Review, $7(1), 63-80$.

Wang, Y. G., Lo, H. P., \& Hui, Y. V (2003). The Antecedents of service quality and product quality and their Influences on bank reputation: evidence from the banking industry in China. Managing Service Quality, 
13(1), 72-83. https://doi.org/10.1108/09604520310456726

Yesmin, F., \& Nasrin, M. (2010). Enhancement of Retail Banking operation of Commercial Banks in Bangladesh Journal of business and technology (Dhaka), 5(2), 166-179. https://doi.org/10.3329/jbt.v5i2.9988

\section{Copyrights}

Copyright for this article is retained by the author(s), with first publication rights granted to the journal.

This is an open-access article distributed under the terms and conditions of the Creative Commons Attribution license (http://creativecommons.org/licenses/by/4.0/). 